\title{
PENINGKATAN PEMAHAMAN KONSEP GEOMETRI MELALUI METODE DEMONSTRASI SISWA KELAS V SDN 186 LEMBANG
}

\author{
Jumrah \\ Dosen Program Studi Pendidikan Matematika \\ STKIP DDI Pinrang \\ E-mail: Jumrah1005@gmail.com
}

\begin{abstract}
ABSTRAK
Penelitian ini merupakan Penelitian Tindakan Kelas (Classroom Action Research) yang dilakukan di SDN 186 Lembang Kab. Pinrang yang bertujuan untuk meningkatkan pemahaman konsep geometri siswa kelas $V$ melalui metode Demonstrasi. Subjek dari penelitian ini adalah siswa kelas V SDN 186 Lembang Kab. Pinrang Tahun ajaran 2016/2017 dengan jumlah siswa 28 orang. Teknik pengumpulan data yang digunakan adalah tes pemahaman konsep yang dilakukan tiap akhir siklus, observasi, refleksi dan respon siswa. Dari data yang terkumpul kemudian dianalisis secara kuantitatif dan kualitatif. Hasil penelitian yang dicapai setelah dianalisis yaitu : (1) pada Siklus I, diperoleh skor rata-rata hasil belajar matematika siswa sebesar 67,36 dengan standar deviasi 11,74 dan persentase siswa yang mencapai KKM sebesar 67,86\%. (2) pada Siklus II, diperoleh skor rata-rata hasil belajar matematika siswa sebesar 71,54 dengan standar deviasi 10,50 dan persentase siswa yang mencapai nilai KKM sebesar 85,71\%. (3) hasil observasi menunjukkan adanya peningkatan aktivitas siswa antara lain siswa menjadi lebih aktif bertanya, menanggapi pertanyaan dan membuat kesimpulan, serta siswa terlihat memperhatikan pelajaran dengan tenang dan fokus sehingga mereka bisa menjawab pertanyaan tentang materi pelajaran dengan baik dan benar. (4) Terjadinya peningkatan pemahaman konsep geometri siswa setelah menerapkan metode demonstrasi.
\end{abstract}

Kata Kunci: Pemahaman Konsep Geometri, Metode Demonstrasi.

\section{PENDAHULUAN}

Pendidikan merupakan proses untuk membantu manusia dalam mengembangkan potensi dirinya sehingga mampu menghadapi setiap perubahan yang terjadi. Melalui pendidikan, manusia dapat meningkatkan pengetahuan, kemampuan, dan kreatifitas terhadap perkembangan ilmu pengetahuan dan teknologi. Guru memegang peranan penting dalam peningkatan mutu pendidikan. karena merekalah yang berhubungan langsung dengan siswa selama proses pembelajaran. Oleh karena itu, guru seyogyanya menerapkan suatu metode pembelajaran yang tepat agar hasil dari proses pembelajaran dapat tercapai secara efektif, efisien, dan signifikan.

Guru tidak hanya dituntut untuk memiliki kemampuan dalam pengalaman teoretis tapi juga harus memiliki kemampuan praktis. Kedua hal ini sangat penting karena seorang guru dalam pembelajaran bukanlah sekedar menyampaikan materi semata tetapi juga harus berupaya agar mata pelajaran yang sedang disampaikan menjadi kegiatan 
pembelajaran yang menyenangkan dan mudah dipahami bagi siswa. Apabila guru tidak dapat menyampaikan materi dengan tepat dan menarik, dapat menimbulkan kesulitan belajar bagi siswa, sehingga mengalami ketidaktuntasan dalam belajarnya. (Sahabuddin: 2007)

Matematika adalah salah satu bidang studi yang diajarkan di segala jenjang pendidikan, mulai dari sekolah dasar (SD) sampai pada jenjang perguruan tinggi. Matematika memegang peranan penting dalam menciptakan Sumber Daya Manusia (SDM) yang berkualitas, sebab dalam matematika terkandung berbagai konsep yang logis dan realistis yang mampu membentuk pola pikir manusia dalam pengembangan ilmu pengetahuan dan teknologi. (Muhkal, 2009).

Dalam matematika terdapat banyak bahan kajian, salah satunya geometri. Geometri banyak menyajikan fakta dan konsep yang bersifat abstrak, maka untuk memahaminya diperlukan upaya kreatif dalam memikirkan, menganalisis, dan mengaplikasikannya dalam berbagai situasi nyata. Oleh karena itu geometri selalu menjadi salah satu bahan kajian matematika yang dianggap sulit bagi sebagian besar siswa, khususnya siswa sekolah dasar (SD) yang perkembangan intelektualnya masih termasuk dalam tahap operasional kongkret, sehingga kemampuan berpikir mereka hanya mampu untuk memahami dan mempelajari konsep-konsep benda real atau nyata. (Suhartono, 2007).

Berdasarkan observasi yang telah dilakukan, diperoleh informasi bahwa proses belajar mengajar di kelas masih cenderung teacher centered dibandingkan student centered. Hal ini tentu saja membuat siswa merasa kurang tertarik dan cepat bosan terhadap pembelajaran matematika. Pada umumya hanya dua atau tiga orang saja yang antusias mengikuti kegiatan yang diberikan, sedangkan selebihnya cenderung bersikap acuh tak acuh terhadap materi pelajaran yang diberikan.

Kesalahan yang dilakukan siswa tidak hanya bersumber pada kemampuan siswa yang kurang, tetapi ada faktor lain yang ikut menentukan keberhasilan siswa dalam belajar matematika. Salah satu diantaranya adalah metode mengajar yang dipilih guru sebagai pengajar dengan pokok bahasan yang diajarkan. Metode mengajar merupakan sarana interaksi guru dengan siswa dalam kegiatan belajar mengajar. Dengan demikian, yang perlu diperhatikan adalah ketetapan metode mengajar yang dipilih dengan tujuan, jenis dan sifat materi pelajaran serta dengan kemampuan guru dalam memahami dan melaksanakan metode tersebut (Roestiyah: 2008). 
Salah satu metode yang dapat digunakan adalah metode demonstrasi. Kelebihan metode demonstrasi adalah untuk membuat proses pembelajaran lebih terfokus sehingga dapat membuat siswa lebih memperhatikan materi yang diajarkan Dengan demonstrasi, proses penerimaan siswa terhadap pelajaran akan lebih berkesan secara mendalam, sehingga membentuk pengertian dengan baik dan sempurna. Juga siswa dapat mengamati dan memperhatikan pada apa yang diperlihatkan guru selama pelajaran berlangsung. Metode demonstrasi adalah metode penyajian pelajaran dengan memperagakan dan mempertunjukkan kepada siswa tentang suatu proses, situasi atau benda tertentu, baik sebenarnya atau hanya sekedar tiruan. (Hendro: 2011)

Pemahaman konsep merupakan kemampuan menangkap makna dan arti dari materi pelajaran yang dipelajari oleh peserta didik. (Abidin: 2011). Dari pernyataan ini, peserta didik dituntut tidak sebatas mengingat kembali pelajaran. Namun lebih dari itu peserta didik mampu mendefenisikan. (Pickard, 2007)

Adapun kriteria dari Pemahaman Konsep:

a. Menyatakan ulang sebuah konsep.

b. Mengklasifikasikan objek-objek menurut sifat-sifat tertentu.

c. Memberi contoh dan non contoh dari konsep.

d. Menyajikan konsep dalam berbagai bentuk representasi matematis.

e. Mengembangkan syarat perlu atau syarat cukup suatu konsep.

f. Menggunakan, memanfaatkan, dan memilih prosedur atau operasi tertentu.

g. Mengaplikasikan konsep dan algoritma pemecahan masalah. (Zulaiha: 2011)

Berkaitan dengan Penelitian ini, Pemahaman konsep geometri yang dimaksud adalah kemampuan peserta didik untuk menggambarkan, menjelaskan, menggolongkan, mengidentifikasi, dan menunjukkan konsep geometri yang telah diterimanya dengan caranya sendiri.

Untuk mencapai keberhasilan tersebut diterapkan metode demonstrasi yang dapat mengubah paradigma mengajar menjadi pembelajaran, sehingga pembelajaran terkesan bermakna. Pembelajaran dengan menggunakan metode demonstrasi adalah pembelajaran yang dilakukan dengan penyajian pelajaran dengan cara memperagakan dan mempertunjukkan kepada siswa tentang suatu proses, situasi atau benda tertentu, baik sebenarnya atau hanya sekedar tiruan. Dalam metode ini tidak terlepas dari penjelasan lisan oleh guru dan nantinya dilanjutkan dengan demonstrator untuk memperlihatkan kepada seluruh kelas suatu proses, misalnya ukuran suatu ruangan dengan menggunakan konsep matematika. Metode demonstrasi biasa digunakan jika siswa ingin mengetahui 
tentang bagaimana mengaturnya, bagaimana proses mengerjakannya, bagaimana proses membuatnya, dan terdiri dari apa. (Suharjana: 2009)

Tindakan dalam proses pembelajaran tersebut yaitu : perencanaan, pelaksanaan tindakan, observasi, dan refleksi. Dengan penerapan metode demonstrasi diharapkan pemahaman konsep geometri siswa dapat meningkat.

\section{METODE PENELITIAN}

\section{A. Jenis Penelitian}

Jenis penelitian ini adalah Penelitian Tindakan Kelas (Classroom action research) dengan tahapan pelaksanaan yang meliputi perencanaan, tindakan, observasi dan refleksi. B. Waktu, Tempat, dan Subjek Penelitian

Penelitian ini telah dilaksanakan pada bulan maret sampai april semester genap 2016/2017 di SDN 186 Pinrang. Subjek penelitian ini adalah siswa kelas V SDN 186 Pinrang yang berjumlah 28 orang terdiri dari 12 laki-laki dan 16 perempuan.

\section{Teknik Pengumpulan Data}

Jenis data yang diperoleh adalah data kuantitatif dan kualitatif:

a. Data kuantitatif diperoleh dari tes pemahaman konsep geometri yang dilakukan pada akhir siklus.

b. Data kualitatif diperoleh dari lembar observasi aktivitas siswa.

\section{Teknik Analisis Data}

Data yang terkumpul selanjutnya dianalisis secara kuantitatif dan kualitatif. Data hasil observasi mengenai situasi belajar dan perilaku siswa dianalisis secara kualitatif. Sedangkan data tentang pemahaman konsep geometri siswa dianalisis secara kuantitatif dengan menggunakan teknik kualifikasi hasil tes pemahaman konsep, yaitu nilai tersebut dikelompokkan berdasarkan kriteria ketuntasan belajar minimal (KKM) yaitu 60 ke atas dikategorikan tuntas dan untuk nilai di bawah 60 dikategorikan tidak tuntas.

\section{E. Indikator Keberhasilan}

\section{Aktivitas}

Indikator keberhasilan penelitian ini dari segi aktivitas adalah apabila 75\% dari jumlah siswa aktif saat proses pembelajaran dengan menggunakan metode demonstrasi alat peraga. Aktivitas siswa yang dimaksud meliputi : Hadir pada saat pembelajaran, memperhatikan penjelasan dari guru dan mencatat pada saat pembelajaran, bertanya tentang materi yang belum dimengerti serta menjawab pertanyaan yang diberikan oleh guru maupun sesama siswa. 


\section{Pemahaman Konsep Geometri}

Indikator keberhasilan dari segi pemahaman konsep geometri adalah apabila persentase perolehan nilai tes pada akhir siklus mengalami peningkatan, yaitu apabila 75\% dari jumlah siswa memperoleh nilai standar Kriteria Kelulusan Minimal (KKM) yang ditentukan oleh sekolah yang bersangkutan yaitu 60 setelah dilaksanakan proses pembelajaran dengan menggunakan metode demonstrasi alat peraga.

\section{HASIL DAN PEMBAHASAN}

\section{A. Hasil Penelitian}

\section{Deskripsi Hasil Penelitian Siklus I}

\section{a. Perencanaan}

Pada tahap perencanaan Siklus I ini, peneliti menelaah silabus pada kurikulum kelas V SDN 186 Pinrang semester genap tahun ajaran 2016/2017 mata pelajaran matematika pada materi pokok "sifat-sifat bangun datar dan bangun ruang" dengan tujuan untuk mengalokasikan waktu yang dapat digunakan dalam penggunaan metode demonstrasi. Siklus pertama dilaksanakan selama empat kali pertemuan. Setelah itu, peneliti membuat Rencana Pelaksanaan Pembelajaran (RPP), Lembar Kerja Siswa (LKS), lembar observasi untuk pengamatan/pencatatan data mengenai keaktifan siswa serta kondisi pembelajaran pada saat pelaksanaan tindakan dan membuat tes pemahaman konsep geometri siklus I. Tahap terakhir dari perencanaan adalah perumusan indikator keberhasilan.

\section{b. Pelaksanaan Tindakan}

Setelah melakukan perencanaan, kemudian dilakukan tindakan berupa pembelajaran dengan metode demonstrasi. Langkah-langkah pengelolaan kelas mengikuti RPP yang telah disusun. Adapun langkah-langkahnya secara umum sebagai berikut:

1) Pada tahap awal, guru menyampaikan bahwa metode pembelajaran yang diterapkan selama penelitian ini adalah metode demonstrasi.

2) Guru memulai pembelajaran dengan menyampaikan materi yang akan dipelajari, dan memotivasi siswa agar mengikuti pelajaran dengan sungguh-sungguh.

3) Sebelum melanjutkan materi, terlebih dahulu guru mereview materi prasyarat.

4) Guru menyajikan materi dengan cara mendemonstrasikannya di depan kelas dengan menggunakan alat peraga yang sebelumnya telah dipersiapkan.

5) Mengarahkan siswa untuk mencatat materi yang dianggap penting. 
6) Untuk mengetahui sejauhmana hasil yang dicapai dari penggunaan metode demonstrasi tersebut, diadakan evaluasi.

7) Guru membagikan LKS dan memberikan kesempatan kepada siswa untuk menanyakan materi yang belum dimengerti

8) Guru memberikan penjelasan tentang materi yang belum dimengerti oleh siswa.

9) Dengan bimbingan guru, siswa menyimpulkan materi pelajaran.

10) Guru memberikan tugas pada siswa untuk dikerjakan di rumah baik secara individu maupun kelompok.

11) Siswa membuat refleksi terhadap materi yang dipelajari secara jelas dan singkat.

12) Setiap pertemuan guru mencatat kejadian yang dianggap penting, seperti kehadiran siswa dan keaktifannya selama proses pembelajaran.

13) Melaksanakan tes siklus

\section{c. Hasil Observasi dan Evaluasi}

Keaktifan siswa dalam proses pembelajaran dapat kita lihat pada hasil observasi yang dilakukan pada setiap pertemuan. Pada setiap pertemuan dicatat atau dilakukan pemantauan terhadap segala aktivitas siswa selama proses pembelajaran berlangsung. Adapun hasil observasi siklus I (4 kali pertemuan) secara umum dapat dilihat pada tabel dibawah ini.

Tabel 1. Hasil Observasi Aktifitas Siswa pada Siklus I

\begin{tabular}{llcc}
\hline No. & \multicolumn{1}{c}{ Aspek yang diobservasi } & Rata-rata & \% \\
\hline 1. & Kehadiran siswa. & 27,5 & 98,21 \\
2. & Siswa yang memperhatikan pembelajaran. & 23 & 82,14 \\
3. & Siswa yang mengerjakan LKS. & 21,67 & 77,38 \\
4. & Siswa yang berpartisipasi secara aktif dalam & 20 & 71,42 \\
& pembelajaran. & & \\
5. & siswa yang menyelesaikan pekerjaan rumahnya & 26,5 & 94,64 \\
& (PR). & & \\
\end{tabular}

\section{Sumber : Data Primer, Tahun: 2016}

Berdasarkan tabel 1 di atas, dapat dilihat bahwa pembelajaran dengan menggunakan metode demonstrasi membuat siswa lebih bersemangat dan aktif dalam pembelajaran. Hal ini dapat dilihat dari persentase kehadiran, siswa yang memperhatikan pembelajaran, siswa yang mengerjakan LKS, serta persentase siswa yang mengerjakan PR (pekerjaan rumah), semuanya di atas $75 \%$ artinya sebagian besar siswa melakukan hal tersebut. Meskipun persentase siswa yang berpartisipasi secara aktif dalam pembelajaran 
masih berada di bawah $75 \%$ yang berarti indicator keberhasilan dari segi aktivitas belum tercapai.

Data kuantitatif merupakan data tentang hasil tes pemahaman konsep geometri siswa kelas V SDN 186 Lembang yang diperoleh melalui tes pemahaman konsep geometri di akhir siklus. Data diperoleh dianalisis dengan menggunakan SPSS for Windows. Tes pemahaman konsep diberikan pada pertemuan keempat di siklus I. Tes ini dalam bentuk uraian, untuk mengetahui sejauh mana pemahaman konsep geometri siswa setelah siklus pertama dilalui. Berikut ini disajikan data tentang skor hasil tes pemahaman konsep geometri siswa kelas V SDN 186 Lembang pada siklus I.

Tabel 2. Statistik Skor Tes Pemahaman Konsep Geometri Siswa pada Siklus I

\begin{tabular}{cc}
\hline Statistik & Nilai Statistik \\
\hline Subjek Penelitian & 28 \\
\hline Skor maksimum ideal & 100 \\
\hline Rata-rata & 67,36 \\
\hline Standar Deviasi & 11,74 \\
\hline Skor Tertinggi & 93 \\
\hline Skor Terendah & 48 \\
\hline
\end{tabular}

Sumber: Data Primer, Tahun: 2016

Jika skor hasil tes pemahaman konsep geometri siswa dikategorikan berdasarkan kriteria ketuntasan yang ditetapkan oleh sekolah, maka akan tampak pada Tabel 3 berikut ini.

Tabel 3. Deskripsi ketuntasan pemahaman konsep geometri siswa kelas V SDN 186 Lembang pada siklus I

\begin{tabular}{cccc}
\hline Skor & Kategori & Frekuensi & Persentase (\%) \\
\hline $0-59,9$ & Tidak Tuntas & 9 & 32,14 \\
\hline \multirow{2}{*}{$60-100$} & Tuntas & 19 & 67,86 \\
\hline \multicolumn{2}{c}{ Jumlah } & 28 & 100 \\
\hline
\end{tabular}

Sumber: Data Primer, Tahun: 2016

Dari Tabel 2 dan 3 dapat disimpulkan bahwa pemahaman konsep geometri siswa kelas V SDN 186 Lembang setelah dilakukan tindakan berupa pembelajaran dengan menggunakan metode demonstrasi pada siklus I dengan skor rata-rata 67,36 yang dicapai oleh siswa dengan standar deviasi 14,23. Data ini menunjukkan bahwa nilai pemahaman 
konsep geometri pada materi sifat-sifat bangun datar yang telah dipelajari pada siklus I berada di sekitar nilai 67,36. Pada siklus I ada 19 orang siswa yang mencapai nilai KKM $(67,86 \%)$ dan 9 orang siswa $(32,14 \%)$ yang belum mencapai KKM. Hal ini menunjukkan bahwa pada siklus I ketuntasan secara klasikal belum tercapai karena jumlah siswa yang memperoleh nilai sama atau di atas KKM belum mencapai $75 \%$.

\section{d. Refleksi}

Setelah pelaksanaan pembelajaran dengan menggunakan metode demonstrasi selama empat kali pertemuan terlihat bahwa keaktifan siswa selama proses pembelajaran sudah mulai meningkat. Namun demikian, dalam kegiatan pembelajaran masih ada beberapa siswa yang bersikap pasif, belum berani untuk mengajukan pertanyaan, kesulitan menjawab pertanyaan baik yang ada di LKS maupun yang diajukan langsung oleh guru dan masih kelihatan bingung saat diminta membuat kesimpulan, dan melakukan aktivitas yang tidak ada hubungannya dengan pelajaran, seperti berkeliaran dan mengobrol dengan teman sebangku.

Dari hasil tes pemahaman konsep geometri Siklus I, terdapat 19 orang dari 28 orang siswa yang mencapai nilai KKM atau hanya 67,86 \% dari jumlah siswa yang berhasil memperoleh nilai $\geq 60$ (nilai KKM yang telah ditetapkan oleh sekolah). Ini berarti indikator keberhasilan dari segi pemahaman konsep geometri siswa yaitu, $75 \%$ dari jumlah siswa mencapai nilai $\geq \mathrm{KKM}$, belum tercapai.

Berdasarkan Hasil refleksi di atas, terlihat bahwa indikator keberhasilan yang telah ditetapkan belum tercapai, dengan demikian diperlukan adanya tindakan perbaikan pembelajaran lebih lanjut, sehingga diputuskan bahwa penelitian ini berlanjut ke siklus berikutnya.

Setelah merefleksi hasil pelaksanaan siklus I, diperoleh suatu gambaran tindakan yang akan dilaksanakan pada siklus II, sebagai perbaikan dari tindakan yang telah dilakukan pada siklus I. Oleh karena itu, peneliti merekomendasikan bahwa pada siklus II akan lebih difokuskan pada tindakan-tindakan baru yang dilakukan antara lain:

1) Diadakan pembentukan kelompok yang beranggotakan 3-4 orang meskipun pembelajaran yang dilakukan bukan pembelajaran kooperatif. Pembentukan kelompok ini dimaksudkan agar siswa yang memiliki kemampuan rendah dapat dibantu oleh temannya yang lebih bisa sehingga siswa yang kesulitan menjawab LKS ini tidak perlu berkeliaran untuk mencari jawaban. Kelompok yang terbentuk dibuat seheterogen mungkin sehingga dalam satu kelompok terdapat siswa berkemampuan tinggi, berkemampuan sedang, dan berkemampuan rendah. 
2) Guru lebih memberikan motivasi kepada siswa bahwa yang berpartisipasi secara aktif dalam pembelajaran misalnya mengajukan pertanyaan, menjawab pertanyaan, dan menyimpulkan materi pelajaran akan memperoleh nilai tambah.

3) Lebih memperketat pengawasan, siswa yang tidak memperhatikan pelajaran atau membuat keributan akan diberi sanksi yaitu dikurangi nilainya atau diminta maju ke depan kelas untuk membantu ibu guru melakukan demonstrasi.

4) Selalu menunjuk siswa secara acak untuk bertanya, menjawab pertanyaan, maupun untuk membuat kesimpulan.

\section{Deskripsi Hasil Penelitian Siklus II}

\section{a. Perencanaan dan Pelaksanaan}

Siklus II dilaksanakan sebanyak tiga kali pertemuan. Perencanaan dan pelaksanaan tindakan pada siklus II ini pada dasarnya mengulang langkah-langkah pada siklus I. Namun yang berbeda adalah pada siklus II dilakukan penyempurnaan dan perbaikan terhadap kendala yang muncul pada siklus I.

\section{b. Hasil Observasi dan Evaluasi}

\section{1) Hasil Analisis Kualitatif}

Tabel 4. Hasil Observasi Aktivitas Siswa pada Siklus II

\begin{tabular}{llcc}
\hline No. & \multicolumn{1}{c}{ Aspek yang diobservasi } & Rata-rata & \% \\
\hline 1. & Kehadiran siswa. & 28 & 100 \\
2. & Siswa yang memperhatikan pembelajaran. & 27,5 & 98,21 \\
3. & Siswa yang mengerjakan LKS. & 26 & 92,86 \\
4. & Siswa yang berpartisipasi secara aktif dalam & 23 & 82,14 \\
& pembelajaran. & & \\
5. & Siswa yang menyelesaikan PR. & 28 & 100 \\
\hline
\end{tabular}

\section{Sumber: Data Primer, Tahun: 2016}

Berdasarkan tabel 4 di atas, dapat dilihat bahwa sikap siswa dalam pembelajaran metode demonstrasi sangat sesuai dengan yang diharapkan. Siswa sangat antusias mengikuti pembelajaran dengan menggunakan metode demonstrasi yang dilakukan yang terlihat persentase kehadirannya sebesar $100 \%$. Siswa juga terlihat lebih percaya diri untuk mengemukakan pendapatnya, bahkan siswa sering berebutan ingin bertanya dan membacakan kesimpulannya dengan cara mengacungkan tangan setinggi-tingginya tetapi ibu guru hanya menunjuk 10 orang untuk mewakili mereka. Metode demonstrasi juga membuat siswa lebih memperhatikan pelajaran dan bisa mengerjakan LKS dengan fokus, 
hal ini terlihat dari persentasenya sebesar 98,21 dan 92,86. Semua siswa yang hadir juga mengerjakan dengan baik PR yang diberikan guru pada pertemuan sebelumnya.

\section{2) Perubahan Sikap Siswa}

Terjadi perubahan pada sikap siswa selama proses pembelajaran di kelas menggunakan metode demonstrasi. Perubahan tersebut merupakan data kualitatif yang diperoleh dari lembar observasi (Tabel 1 dan Tabel 4) yang dicatat oleh mahasiswa lain yang membantu peneliti selama penelitian berlangsung adapun perubahan yang dimaksud:

a) Meningkatnya persentase kehadiran siswa, dari siklus I sebanyak $98,21 \%$ selama empat kali pertemuan menjadi $100 \%$ pada siklus II dengan jumlah pertemuan sebanyak tiga kali dan jumlah siswa 28 orang. Hal ini berarti bahwa semakin meningkatnya motivasi siswa untuk mengikuti pelajaran matematika.

b) Perhatian siswa pada proses pelajaran makin baik. Hal ini dapat dilihat meningkatnya persentase siswa yang memperhatikan demonstrasi dari sekitar 82 $\%$ pada siklus I menjadi $98 \%$ pada siklus II. Selain itu persentase siswa yang melakukan kegiatan lain selama pembelajaran semakin menurun dari siklus I 19,05\% menjadi 5,36\% pada siklus II.

c) Siswa juga lebih berpartisipasi aktif dalam pembelajaran, sebagian besar siswa mengacungkan tangan setinggi-tingginya saat ibu guru akan memilih siswa yang harus bertanya, menanggapi atau menyimpulkan materi pelajaran, akan tetapi guru hanya akan menunjuk maksimal 10 orang sebagai perwakilan dari yang lain.

d) Keaktifan siswa dalam mengerjakan LKS juga meningkat dari 77,38 \% menjadi $92,86 \%$.

e) Keaktifan siswa dalam menyelesaikan pekerjaan rumah (PR) juga mengalami peningkatan, ini dilihat dari semakin meningkatnya siswa yang mengumpulkan tugas rumahnya pada siklus I sebesar 94,64\% dan pada siklus II sebesar $100 \%$.

\section{3) Hasil Analisis Kuantitatif Siklus II}

Setelah diberikan tes pemahaman konsep untuk menguji pemahaman siswa terhadap materi yang telah dibahas pada siklus II ini, dapat dikatakan bahwa hasil yang diperoleh siswa mengalami peningkatan jika dibandingkan dengan tes yang dilaksanakan di akhir siklus I. Sebagaimana dutunjukkan pada tabel 5 di bawah ini. 
Tabel 5. Statistik Skor Tes Pemahaman Konsep Geometri Siswa pada Siklus II

\begin{tabular}{cc}
\hline Statistik & Nilai Statistik \\
\hline Subjek Penelitian & 28 \\
\hline Skor maksimum ideal & 100 \\
\hline Rata-rata & 71,53 \\
\hline Standar Deviasi & 10,50 \\
\hline Skor Tertinggi & 94 \\
\hline Skor Terendah & 54 \\
\hline
\end{tabular}

Sumber: Data Primer, Tahun: 2016

Jika skor hasil tes pemahaman konsep geometri siswa dikategorikan berdasarkan kriteria ketuntasan yang ditetapkan oleh sekolah, maka akan tampak pada Tabel 6 berikut ini.

Tabel 6. Deskripsi ketuntasan pemahaman konsep geometri siswa kelas V SDN 186 Lembang pada siklus II

\begin{tabular}{cccc}
\hline Skor & Kategori & Frekuensi & Persentase (\%) \\
\hline $0-59,9$ & Tidak Tuntas & 4 & 14,29 \\
\hline $60-100$ & Tuntas & 24 & 85,71 \\
\hline \multicolumn{2}{c}{ Jumlah } & 28 & 100 \\
\hline
\end{tabular}

Sumber: Data Primer, Tahun: 2016

Dari Tabel 5 dan 6 maka dapat disimpulkan bahwa hasil belajar matematika siswa kelas V SDN 186 Lembang setelah dilakukan tindakan pembelajaran dengan menggunakan metode demonstrasi pada siklus II memiliki skor rata-rata 71,53 yang mungkin dicapai oleh siswa dengan standar deviasi 10,50. Data ini menunjukkan bahwa skor hasil tes pemahaman konsep geometri siswa kelas V SDN 186 Lembang pada materi sifat-sifat bangun ruang yang dipelajari pada siklus II berada di sekitar nilai 71,53.Pada siklus II ini terdapat 22 orang siswa yang mencapai nilai KKM dengan persentase 85,71 $\%$ dan hal tersebut sudah mencapai standar yang diharapkan. Meskipun masih ada 4 orang siswa $(14,29 \%)$ yang belum mencapai KKM. 


\section{c. Refleksi Siklus II}

Aktivitas siswa pada siklus II mengalami kemajuan ke arah positif yang signifikan. Siswa yang pada awalnya kelihatan malu/ragu mengajukan pertanyaan, memberi tanggapan, dan membacakan kesimpulannya, akhirnya berani untuk berpartisipasi secara aktif dalam pembelajaran baik itu dalam hal bertanya, menanggapi, maupun menyimpulkan materi pelajaran. Siswa yang tadinya sering berkeliaran dan membuat keributan menjadi memperhatikan pembelajaran dengan tenang. Begitu juga siswa yang tadinya kesulitan menjawab pertanyaan yang diberikan oleh guru dan kesulitan mengerjakan LKS, akhirnya bisa menjawab pertanyaan tersebut dengan benar. Karena semua siswa telah berpartisipasi secara aktif dalam proses pembelajaran berarti indikator keberhasilan dari segi aktivitas siswa telah tercapai.

Sedangkan hasil tes pemahaman konsep geometri Siklus II menunjukkan bahwa terdapat 24 orang dari 28 orang siswa yang mencapai nilai KKM atau hanya 85,71\% dari jumlah siswa yang berhasil memperoleh nilai $\geq 60$ (nilai KKM yang telah ditetapkan oleh sekolah). Ini berarti indikator keberhasilan dari segi pemahaman konsep geometri siswa yaitu, $75 \%$ dari jumlah siswa mencapai nilai $\geq \mathrm{KKM}$, juga telah tercapai.

Berdasarkan hasil refleksi di atas, terlihat bahwa indikator keberhasilan yang telah ditetapkan telah tercapai, dengan demikian dapat disimpulkan bahwa pelaksanaan pembelajaran dengan menggunakan metode demonstrasi dapat meningkatkan pemahaman konsep geometri siswa kelas V SDN 186 Lembang, sehingga penelitian ini terhenti di siklus II.

\section{B. Pembahasan}

Berdasarkan hasil observasi yang dilakukan di SDN 186 Lembang Kab. Pinrang, diketahui bahwa siswa kelas V SDN 186 Lembang Kab. Pinrang mengalami kesulitan dalam belajar geometri. Kebanyakan siswa kelas V ini masih memiliki pemahaman konsep geometri yang salah, terutama konsep-konsep geometri datar. Masih banyak siswa kelas V SDN 186 Lembang Kab. Pinrang yang beranggapan bahwa segiempat itu adalah persegi, padahal yang termasuk segiempat bukan cuma persegi, persegi panjang, jajargenjang, belahketupat, dan semua bangun datar yang memiliki 4 sisi juga didefinisikan sebagai segiempat, mereka juga beranggapan bahwa yang termasuk segitiga hanya segitiga siku-siku dan segitiga sama sisi, padahal semua bangun datar yang memiliki 3 sisi adalah segitiga. Kesulitan belajar geometri mereka juga terlihat dari ratarata ulangan harian geometri pada semester ganjil tahun ajaran 2016/2017 yang masih 
sangat rendah yaitu 53,7 dan hanya 13 orang dari 28 siswa yang tuntas sebelum diadakan remedial.

Berdasarkan hasil wawancara dengan guru wali kelas $\mathrm{V}$, dalam hal ini ibu Nasirah, S.Pd, ditemukan bahwa selain memiliki pemahaman konsep geometri yang rendah siswa kelas V SDN 186 Lembang ini juga bersikap pasif dalam pembelajaran. Sebagian besar dari mereka masih merasa malu/ragu untuk berpartisipasi secara aktif di dalam kelas. Untuk mengatasi hal ini, peneliti menawarkan sebuah solusi berupa sebuah metode pembelajaran yang jarang digunakan padahal sangat efektif jika digunakan dalam pembelajaran matematika khususnya pada materi geometri yaitu metode demonstrasi.

Pembelajaran dengan menggunakan metode demontrasi dalam penelitian ini dilakukan dengan penyajian materi dengan cara demonstrasi oleh guru dan dibantu oleh beberapa siswa yang dianggap tidak memperhatikan penjelasan/demonstrasi yang dilakukan oleh guru. LKS yang digunakan berisi langkah-langkah demonstrasi yang akan dilakukan guru dan juga beberapa pertanyaan. Jadi siswa diharapkan menjawab pertanyaan yang ada dalam LKS setelah melihat demonstrasi yang dilakukan ibu guru. Saat guru mendemonstrasikan materi siswa diharapkan mencatat hal yang dianggap penting sambil menjawab pertanyaan yang ada di LKS. Pada penelitian ini, guru harus menunjuk secara acak siswa untuk bertanya, memberi tanggapan, atau membuat kesimpulan, hal ini dimaksudkan agar siswa tidak merasa ragu/malu lagi untuk berpartisipasi secara aktif dalam pembelajaran dan juga sebagai motivasi untuk meningkatkan rasa percaya diri siswa. Pada akhir pertemuan siswa harus menyimpulkan sendiri materi pelajaran yang telah mereka dapatkan dengan arahan dari ibu guru.

Hasil analisis kuantitatif yang telah dilakukan menunjukkan bahwa hasil tes kemampuan pemahaman konsep geometri siswa Kelas V SDN 186 Lembang pada materi pokok sifat-sifat bangun datar dan bangun ruang dengan menerapakan metode demonstrasi dapat membuat ketuntasan secara klasikal tercapai tanpa perlu dilakukan remedial. Selain tercapai ketuntasan klasikal juga mengalami peningkatan dari Siklus I ke Siklus II. Hal ini terlihat dari rata-rata kemampuan pemahaman konsep geometri pada siklus I yaitu 67,36 menjadi 71,53 pada siklus II dari 28 siswa, atau dari segi klasikal yaitu 75\% dari KKM (60) yang ditetapkan oleh sekolah, dari 60,71\% menjadi 85,71\%.

Selanjutnya berdasarkan analisis kualitatif hasil observasi siswa pada saat proses pembelajaran berlangsung di kelas menunjukkan bahwa persentase kehadiran, motivasi, perhatian, keaktifan serta rasa percaya diri siswa kelas V SDN 186 Lembang dalam mengikuti proses pembelajaran dengan menggunakan metode demonstrasi pada materi 
geometri menjadi lebih baik. Hal ini berkat hasil refleksi pada siklus I, maka dilakukan beberapa perbaikan yang dianggap perlu untuk peningkatan aktivitas pada siklus selanjutnya. Bahkan pada minggu kedua di siklus II Sebagian besar siswa terlihat berpartisipasi secara aktif dalam pembelajaran. Siswa yang tadinya selalu berkeliaran dan membuat keributan sudah memperhatikan pelajaran dengan tenang, siswa yang merasa malu/ragu untu bertanya, memberi tanggapan, dan membuat kesimpulan sudah termotivasi untuk bertanya, menanggapi dan berani menyimpulkan. Hasil yang diperoleh sejalan dengan hasil penelitian Yatmoko (2011) yang juga mengatakan bahwa metode demonstrasi dapat meningkatkan hasil belajar siswa.

\section{KESIMPULAN DAN SARAN}

\section{A. Kesimpulan}

1. Setelah dilakukan pembelajaran dengan menggunakan metode demonstrasi, kemampuan pemahaman konsep geometri siswa kelas V SDN 186 Lembang pada materi pokok sifat-sifat bangun datar dan bangun ruang mengalami peningkatan. Hal ini terlihat dari meningkatnya persentase jumlah siswa yang mencapai nilai sama atau lebih besar dari KKM (yang telah ditentukan sekolah sebesar 60), yaitu pada siklus I sebesar 67,86\% meningkat pada siklus II menjadi $85,71 \%$.

2. Keaktifan siswa dalam proses pembelajaran juga mengalami peningkatan dalam hal kehadiran siswa dalam proses belajar mengajar, perhatian siswa dalam pembahasan materi pelajaran, keaktifan siswa dalam mengerjakan LKS, siswa lebih berpartisipasi secara aktif dalam pembelajaran, misalnya aktif bertanya, menjawab pertanyaan, menanggapi, dan membuat kesimpulan, kesungguhan siswa dalam menyelesaikan pekerjaan rumahnya (PR).

\section{B. Saran}

Untuk memaksimalkan kemampuan pemahaman konsep geometri siswa, maka Pembelajaran geometri dengan metode demonstrasi perlu diterapkan dan dipertimbangkan sebagai salah satu alternatif metode pembelajaran materi geometri, agar siswa dapat memahami konsep geometri yang diajarkan dengan baik. 


\section{DAFTAR PUSTAKA}

Abidin, Zaenal. 2011. Definisi Pemahaman Menurut Para Ahli. http://www.masbied.com/2011/09/02/definisi-pemahaman-menurut-parahli.html. Diakses pada tanggal 25 Januari 2016

Hendro. 2011. Metode Demonstrasi. http://dapah.blogspot.com/2011/11/normal-0-falsefalse-false-en-us-x-none_29.html Diakses pada tanggal 22 Desember 2015

Muhkal, Mappaita. 2009. Materi Kuliah Strategi Belajar Mengajar Matematika. Makassar: FMIPA UNM

Pickard, Marry. 2007. The New Booms Taxonomy An Overview For Family And Consumer Sciences. Journal of Family and Consumer Science Education. 25(1)

Roestiyah. 2008. Strategi Belajar Mengajar. Jakarta: Rineka Cipta

Sahabuddin. 2007. Mengajar dan Belajar. Makassar: Badan Penerbit UNM.

Suharjana, Agus. 2009. Pemanfaatan alat peraga sebagai Media pembelajaran Matematika. Yogyakarta: Pusat Pengembangan Dan Pemberdayaan Pendidik Dan Tenaga Kependidikan Indonesia

Suhartono. 2007. Geometri I. Makassar: Jurusan Matematika FMIPA UNM

Yatmoko, susilo. 2011. Penerapan Metode Demonstrasi Dengan Media Benda Asli Untuk Meningkatkan Hasil Belajar Ilmu Pengetahuan Alam Siswa Kelas V Semester I. http://susilofy.wordpress.com/ Diakses pada tanggal 22 Desember 2015

Zulaiha. 2011. Definisi Pemahaman Konsep. http://ahli-definisi.blogspot.com/definisipemahaman-konsep.html Diakses pada tanggal 25 Januari 2016 